\title{
Influence of mineral and modified fertilizers on oat yield
}

\author{
Galina Sajdiasheva ${ }^{1, *}$, Alevtina Kulikova ${ }^{2}$, Alexander Laschenkov ${ }^{2}$, and Sergey Nemtsev ${ }^{1}$ \\ ${ }^{1}$ Ulyanovsk Agricultural Research Institute - Branch of Samara Federal Research Center of the Russian Academy of Sciences, 433315 \\ Timiriazevskiy settlement, Ulyanovsk region, Russia \\ ${ }^{2}$ Ulyanovsk State Agricultural University, 432017 Ulyanovsk, Russia
}

\begin{abstract}
The paper presents the study of the influence of mineral and modified fertilizers on the formation of yield and quality of oat grain in the Middle Volga. The study was carried out in 2016-2018 on the experimental field of Ulyanovsk Research Institute of Agriculture. The meteorological conditions of vegetation periods during the study varied in temperature and moistening. Three-year studies made it possible to confirm that the administration of a half-dose biomodified azophoska $\left(1 / 2 \mathrm{~N}_{15} \mathrm{P}_{15} \mathrm{~K}_{15 \mathrm{~m}}\right)$ increased grain yield in relation to the absolute control on all study backgrounds by $0.13-0.49$ t/ha. The greatest effect of fertilizers was observed against the background of ammonium nitrate $\left(\mathrm{NH}_{4} \mathrm{NO}_{3 \mathrm{~m}}\right)$ applied under presowing cultivation at a dose of 40 $\mathrm{kg}$ active ingredient/ha treated with microbiological preparation BisolbiFit. Yield enhancement was accompanied by a relative decrease of protein content of oat grains ranging from 11.3 to $12.4 \%$. There is a negative relation $(\mathrm{r}=-0.76)$ between the mass of 1000 grains and the protein content.
\end{abstract}

\section{Introduction}

Due to continuous increase in the cost of mineral fertilizers and possible negative effects on product quality and the environment, it is important to find ways to reduce their doses without losing their efficiency. According to some scientists [1,2], the use of biological preparations made on the basis of effective microbial strains is becoming ever more relevant. It is proposed to use them not only for pre-sowing seed treatment of seeds or vegetative plants, but directly applying them to mineral fertilizers during planting (biomodified fertilizers). According to the authors, the latter allows reducing the doses of fertilizers and increasing the utilization rates of their nutrients, as well as improving plant nutrition.

The above led to the purpose of the study, i.e. to study the impact of mineral and biomodified fertilizers on the formation of oat yield.

\section{Materials and methods}

The study was carried out on a stationary site of the experimental field of Ulyanovsk Agricultural Research Institute - Branch of Samara Federal Research Center of the Russian Academy of Sciences in 2016-2018 in grain crop rotation: complete fallow - winter wheat - spring wheat - barley - oat. The soil of the experimental field contains leached heavy loamy chernozem with humus content of 6.43-6.62 \%, available phosphorus and potassium compounds (according to Chirikov) - 214-228 and $101-117 \mathrm{mg} / \mathrm{kg}$ of soil, $\mathrm{pH}_{\mathrm{KCl}}-6.3-6.8$ units.

Research objects:
- azophosca - mineral fertilizer containing $15 \%$ nitrogen, phosphorus and potassium (NPK);

- bisolbifit - microbiological preparation based on rhizospheric bacteria strain Bacillius Subtilis Ch-13. Bacteria cam synthesize substances that inhibit the development of plant pathogenic fungi and bacteria, as well as substances that stimulate plant growth. Presowing treatment of seeds with Bisolbifite biopreparation (dry form) was carried out 1 day prior to sowing at the rate of 400-600 g/t, consumption of working solution $-101 / t$;

- biomodified fertilizer $\left(\mathrm{NPK}_{\mathrm{m}} 1 / 2\right.$ and $\left.\mathrm{NPK}_{\mathrm{m}}\right)$. A dry form of BisolbiFit biopreparation was used to prepare a biomodified fertilizer at a rate of $4 \mathrm{~kg}$ per 1 ton of fertilizer. The biopreparation was applied to a mineral fertilizer on the day of its application to the soil.

Table 1. Scheme of the experiment

\begin{tabular}{|c|c|c|c|}
\hline Option & & ckgrou & \\
\hline 1. Control without fertilizers & \multirow{5}{*}{ 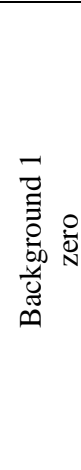 } & \multirow{5}{*}{ 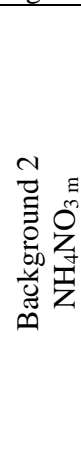 } & \multirow{5}{*}{ 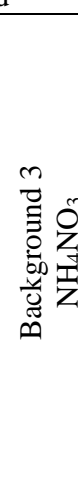 } \\
\hline $\begin{array}{l}\text { 2. Bisolbifite }- \text { pre-sowing seed } \\
\text { treatment }(400-600 \mathrm{~g} / \mathrm{t})\end{array}$ & & & \\
\hline $\begin{array}{l}\text { 3. NPK - azophosca at a dose of } 15 \\
\mathrm{~kg} \text { active ingredient/ha }\end{array}$ & & & \\
\hline $\begin{array}{l}\text { 4. NPKm - treatment of azophosca } \\
\text { granules with biopreparation at a } \\
\text { dose } \\
\text { of } 15 \mathrm{~kg} \text { active ingredient/ha }\end{array}$ & & & \\
\hline $\begin{array}{l}5.1 / 2 \mathbf{N P K m}-\text { treatment of } \\
\text { azophosca granules with } \\
\text { biopreparation at a dose } \\
\text { of } 7.5 \mathrm{~kg} \text { active ingredient } / \mathrm{ha}\end{array}$ & & & \\
\hline
\end{tabular}

* Corresponding author: Galina_83@list.ru 
The field experiment was carried out according to the developed scheme (Table 1). The efficiency of fertilizers was evaluated in 3 backgrounds. The first background remained as a control (zero, absolute control), the second included ammonia nitrate in a dose of $40 \mathrm{~kg} / \mathrm{ha}$ treated with Bisolbifite biopreparation, the third - ammonia nitrate in a pure form in a dose of $40 \mathrm{~kg}$ active ingredient/ha introduced for pre-plant cultivation.

The accounting area made $100 \mathrm{~m}^{2}(4 * 25)$, triple application, random location. The organization of field experiments, selection of soil and plant samples, observations and laboratory analyses were carried out according to corresponding GOST standards.

\section{Results and discussion}

The change of the crop yield structure makes it possible to identify those elements that prevail in the formation of yields in specific soil-climatic conditions [3-5]. At the same time, it is necessary to analyze the dynamics of each element of crop productivity, which participates in yield formation. Table 2 shows the oat yield structure in experiments.

The main basic component of yield formation is the optimal number of productive stems per unit area $[6,7]$. The correlation dependence of oat grain yield with this indicator made 0.76. Depending on the dose and type of fertilizer, the number of productive stems varied within $273-311 \mathrm{pcs} / \mathrm{m}^{2}$ in the control option, $297-315 \mathrm{pcs} / \mathrm{m}^{2}$ in the option with BisolbiFit (pre-sowing seed treatment), $300-320 \mathrm{pcs} / \mathrm{m}^{2}$ in the option with Azophosca in its pure form $\left(\mathrm{N}_{15} \mathrm{P}_{15} \mathrm{~K}_{15}\right), 312-157 \mathrm{pcs} / \mathrm{m}^{2}$ in the option $\mathrm{N}_{15} \mathrm{P}_{15} \mathrm{~K}_{15 \mathrm{~m}}$ and $314-317 \mathrm{pcs} / \mathrm{m}^{2}$ in the option $1 / 2 \mathrm{~N}_{15} \mathrm{P}_{15} \mathrm{~K}_{15 \mathrm{~m}}$. The highest number of productive stems per $1 \mathrm{~m}^{2}$ was observed for $\mathrm{N}_{15} \mathrm{P}_{15} \mathrm{~K}_{15 \mathrm{~m}}$ and $\mathrm{N}_{15} \mathrm{P}_{15} \mathrm{~K}_{15}$ in background $2-\mathrm{NH}_{4} \mathrm{NO}_{3 \mathrm{~m}}$ (Table 2 ).

Table 2. Oat yield structure depending on fertilizer and biopreparation (2016-2018)

\begin{tabular}{|c|c|c|c|c|c|}
\hline 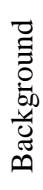 & Option & 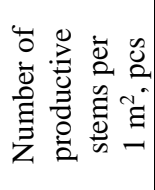 & 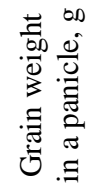 & 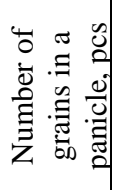 & 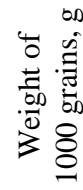 \\
\hline \multirow{5}{*}{ 氹 } & 1. Control & 273 & 0.85 & 23.9 & 35.6 \\
\hline & 2. BisolbiFit & 297 & 0.89 & 24.3 & 36.6 \\
\hline & 3. $\mathrm{N}_{15} \mathrm{P}_{15} \mathrm{~K}_{15}$ & 300 & 0.90 & 24.3 & 37.0 \\
\hline & 4. $\mathrm{N}_{15} \mathrm{P}_{15} \mathrm{~K}_{15 \mathrm{~m}}$ & 312 & 0.90 & 24.2 & 37.2 \\
\hline & 5. $1 / 2 \mathrm{~N}_{15} \mathrm{P}_{15} \mathrm{~K}_{15 \mathrm{~m}}$ & 314 & 0.89 & 24.0 & 37.0 \\
\hline \multirow{5}{*}{ 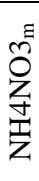 } & 1. Control & 311 & 0.90 & 24.2 & 37.2 \\
\hline & 2. BisolbiFit & 315 & 0.95 & 25.4 & 37.4 \\
\hline & 3. $\mathrm{N}_{15} \mathrm{P}_{15} \mathrm{~K}_{15}$ & 320 & 1.07 & 27.8 & 38.4 \\
\hline & 4. $\mathrm{N}_{15} \mathrm{P}_{15} \mathrm{~K}_{15 \mathrm{~m}}$ & 327 & 1.08 & 27.8 & 38.8 \\
\hline & 5. ${ }^{1 / 2} \mathrm{~N}_{15} \mathrm{P}_{15} \mathrm{~K}_{15 \mathrm{~m}}$ & 317 & 0.97 & 25.7 & 37.7 \\
\hline \multirow{5}{*}{$\begin{array}{l}\text { ô } \\
Z \\
\text { 党 } \\
\text { 乙 }\end{array}$} & 1. Control & 308 & 0.89 & 24.1 & 37.0 \\
\hline & 2. BisolbiFit & 313 & 0.90 & 24.1 & 37.3 \\
\hline & 3. $\mathrm{N}_{15} \mathrm{P}_{15} \mathrm{~K}_{15}$ & 317 & 1.0 & 26.5 & 37.8 \\
\hline & 4. $\mathrm{N}_{15} \mathrm{P}_{15} \mathrm{~K}_{15 \mathrm{~m}}$ & 320 & 1.0 & 26.3 & 38.0 \\
\hline & 5. ${ }^{1 / 2} \mathrm{~N}_{15} \mathrm{P}_{15} \mathrm{~K}_{15 \mathrm{~m}}$ & 318 & 0.98 & 26.5 & 37.0 \\
\hline
\end{tabular}

The structural indicator "number of grains in a panicle" plays a certain role in yield formation. On average over 3 years of study, the minimum number was noted in control options of all studied backgrounds, respectively: 23.9 pieces; 24.2 pieces; 24.1 pieces. In all options that used mineral and modified fertilizers were characterized by the largest amount of grains. In the option with biopreparation, the number of grains in a panicle varied from 24.3 to 25.4 pieces.

A direct bond $(r=0.97)$ was noted in the analysis of such indicators as the "number of grains in a panicle" and the "weight of grains in a panicle". Consequently, these grain quality indicators have similar changes depending on the type of fertilizer.

The weight of 1000 grains characterizes the degree of grain ripeness, density of its tissues and the amount of endosperm in a grain, which impacts sowing and commercial qualities of grain $[3,5]$. Over the years of study, the weight of 1000 grains fluctuated in the range of 35.6-38.8 g. Without the use of mineral fertilizers and biopreparation in a zero background it amounted to $35.6 \mathrm{~g} ; 37.2 \mathrm{~g}$ in $\mathrm{NH}_{4} \mathrm{NO}_{3 \mathrm{~m}}$ and $37.0 \mathrm{~g}$ in pure ammonium nitrate. The application of fertilizers positively affected the studied indicator thus increasing its value by $0.8-1.6 \mathrm{~g}$. Compared to the zero background, the weight of 1000 grains after the application of mineral, biomineral fertilizers and biopreparation increased in $\mathrm{NH}_{4} \mathrm{NO}_{3} \mathrm{~m}$ background from 37.2 to $38.8 \mathrm{~g}$ and from 37.0 to $38.0 \mathrm{~g}$ in $\mathrm{NH}_{4} \mathrm{NO}_{3}$ background.

The correlation analysis made it possible to establish the dependence of yield on the main elements of oat yield structure. Such indicators as the "number of productive stems - yield", "weight of grains in a panicle - yield", "weight of 1000 grains - yield" and the "number of grains in a panicle - yield" are marked by direct correlation, which coefficients made 0.76, 0.86, 0.88 and 0.81 respectively (Fig. 1).

Grain yield is the main indicator in the evaluation of studied plant cultivation techniques. Its formation largely depends on plant growing conditions. In the process of growth and development, certain requirements are placed on external environmental conditions, which are related to the nature and intensity of physical and biochemical processes. One of the most effective and fast-acting factors improving plant nutrition and increasing oat yield is the use of mineral fertilizers. In recent decades, microbiological preparations, which due to their additional involvement in agrocenosis of the main elements of mineral nutrition, also contribute to the increase of grain productivity of the culture, is considered a promising direction $[3,8]$.

As a result of our studies over 2016-2018, there was a positive effect of mineral and biomodified fertilizers, as well as biopreparations on the oat yield. On average over 3 years the yield of oats grain (Table 3 ) varied from 2.15 to $2.71 \mathrm{t} / \mathrm{ha}$, without fertilizers it made $2.24 \mathrm{t} / \mathrm{ha}$, with $\mathrm{NH}_{4} \mathrm{NO}_{3 \mathrm{~m}}-2.57 \mathrm{t} / \mathrm{ha}$ and $\mathrm{NH}_{4} \mathrm{NO}_{3}-2.38 \mathrm{t} / \mathrm{ha}$.

Without the use of mineral fertilizers and biopreparations the grain yield reached $2.15 \mathrm{t} / \mathrm{ha}$, in the background of $\mathrm{NH}_{4} \mathrm{NO}_{3 \mathrm{~m}}-2.43 \mathrm{t} / \mathrm{ha}$ and in the background of ammonium nitrate in pure form -2.25 t/ha (Table 3). The use of azophoska increased yields in all studied backgrounds by $0.13,0.18$ and $0.15 \mathrm{t} / \mathrm{ha}$, 
respectively. Biomodification of mineral fertilizer $\left(\mathrm{N}_{15} \mathrm{P}_{15} \mathrm{~K}_{15 \mathrm{~m}}\right)$ contributed to further increase of oat yield.

The use of a half-dose biomodified azophoska $\left(1 / 2 \mathrm{~N}_{15} \mathrm{P}_{15} \mathrm{~K}_{15 \mathrm{~m}}\right)$ increased grain yields relative to the
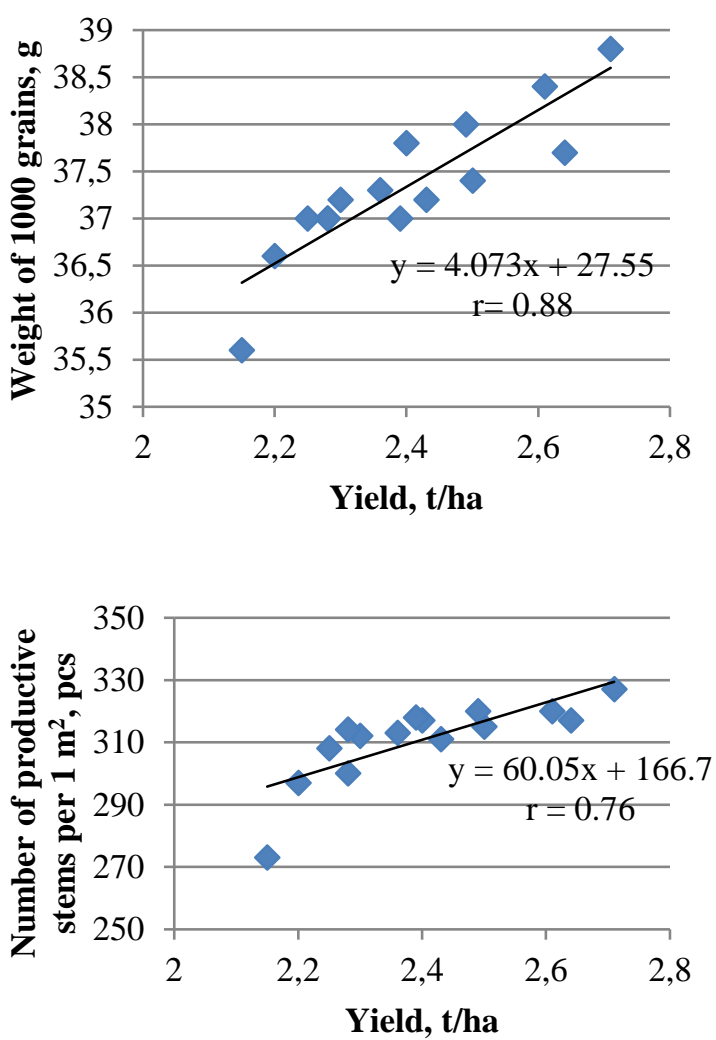

absolute control by $0.13 \mathrm{t} / \mathrm{ha}$ (background 1 ), $0.49 \mathrm{t} / \mathrm{ha}$ (background 2) and 0.24 t/ha (background 3).
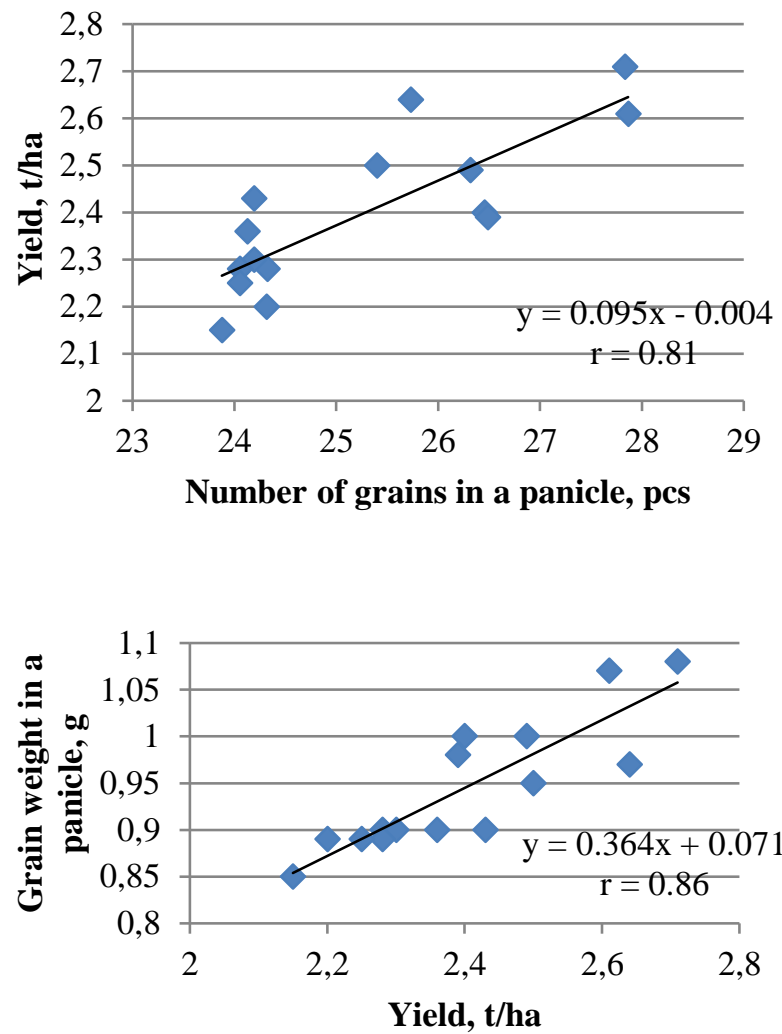

Fig. 1. Dependence of oat yield on yield structure elements, 2016-2018

Table 3. Oat yield depending on fertilizers and biopreparation, 2016-2018

\begin{tabular}{|c|c|c|c|c|}
\hline \multirow{2}{*}{ Background } & \multirow[t]{2}{*}{ Option } & \multirow{2}{*}{$\begin{array}{c}\text { Yield, } \\
\text { t/ha }\end{array}$} & \multicolumn{2}{|c|}{$\begin{array}{l}\text { Addition to the } \\
\text { control }\end{array}$} \\
\hline & & & $\mathrm{t} / \mathrm{ha}$ & $\%$ \\
\hline \multirow{5}{*}{ Zero } & 1. Control & 2.15 & - & - \\
\hline & 2. BisolbiFit & 2.20 & 0.05 & 2.3 \\
\hline & 3. $\mathrm{N}_{15} \mathrm{P}_{15} \mathrm{~K}_{15}$ & 2.28 & 0.13 & 6.0 \\
\hline & 4. $\mathrm{N}_{15} \mathrm{P}_{15} \mathrm{~K}_{15 \mathrm{~m}}$ & 2.30 & 0.15 & 7.0 \\
\hline & 5. $1 / 2 \mathrm{~N}_{15} \mathrm{P}_{15} \mathrm{~K}_{15 \mathrm{~m}}$ & 2.28 & 0.13 & 6.0 \\
\hline \multicolumn{2}{|c|}{ Average for background } & 2.24 & & \\
\hline \multirow{5}{*}{$\mathrm{NH}_{4} \mathrm{NO}_{3} \mathrm{~m}$} & 1. Control & 2.43 & - & - \\
\hline & 2. BisolbiFit & 2.50 & 0.07 & 3,0 \\
\hline & 3. $\mathrm{N}_{15} \mathrm{P}_{15} \mathrm{~K}_{15}$ & 2.61 & 0.18 & 7 \\
\hline & 4. $\mathrm{N}_{15} \mathrm{P}_{15} \mathrm{~K}_{15 \mathrm{~m}}$ & 2.71 & 0.28 & 12 \\
\hline & 5. $1 / 2 \mathrm{~N}_{15} \mathrm{P}_{15} \mathrm{~K}_{15 \mathrm{~m}}$ & 2.64 & 0.21 & 9 \\
\hline \multicolumn{2}{|c|}{ Average for background } & 2.57 & & \\
\hline \multirow{5}{*}{$\mathrm{NH}_{4} \mathrm{NO}_{3}$} & 1. Control & 2.25 & - & - \\
\hline & 2. BisolbiFit & 2.36 & 0.11 & 5 \\
\hline & 3. $\mathrm{N}_{15} \mathrm{P}_{15} \mathrm{~K}_{15}$ & 2.40 & 0.15 & 7 \\
\hline & 4. $\mathrm{N}_{15} \mathrm{P}_{15} \mathrm{~K}_{15 \mathrm{~m}}$ & 2.49 & 0.24 & 11 \\
\hline & 5. ${ }^{1} / 2 \mathrm{~N}_{15} \mathrm{P}_{15} \mathrm{~K}_{15 \mathrm{~m}}$ & 2.39 & 0.05 & 6 \\
\hline \multicolumn{2}{|c|}{ Average for background } & 2.38 & & \\
\hline LSD05 $_{4} \quad \mathrm{~F}$ & \multicolumn{4}{|c|}{ Factor $\mathrm{A}-0.05 ;$ Factor $\mathrm{B}-0.06$; Factor $\mathrm{AB}-0.12$} \\
\hline
\end{tabular}

It was also found that a higher yield was formed in the background with ammonium nitrate $\left(\mathrm{NH}_{4} \mathrm{NO}_{3 \mathrm{~m}}\right)$ at a dose of $40 \mathrm{~kg}$ active ingredient/ha treated with microbiological preparation BisolbiFit.
The efficiency of any crop cultivation approach is characterized not only by yield, but also by the quality of its products. Table 4 shows the assessment of oat quality caused by grain biochemical composition.

Table 4. Oat grain quality over 2016-2018

\begin{tabular}{|c|c|c|c|c|}
\hline Option & $\begin{array}{l}\text { Weight of } \\
1000 \text { grains, } \\
\text { g }\end{array}$ & $\begin{array}{c}\text { Protein, } \\
\%\end{array}$ & $\begin{array}{c}\text { Grain-unit, } \\
\text { g/l }\end{array}$ & $\begin{array}{c}\text { Hoodness, } \\
\%\end{array}$ \\
\hline \multicolumn{5}{|c|}{ Background 1 - zero } \\
\hline 1. Control & 35.6 & 12.4 & 470 & 33.1 \\
\hline 2. BisolbiFit & 36.6 & 12.1 & 472 & 33.0 \\
\hline 3. $\mathrm{N}_{15} \mathrm{P}_{15} \mathrm{~K}_{15}$ & 37.0 & 11.8 & 480 & 29.6 \\
\hline 4. $\mathrm{N}_{15} \mathrm{P}_{15} \mathrm{~K}_{15 \mathrm{~m}}$ & 37.2 & 11.5 & 478 & 27.3 \\
\hline 5. $1 / 2 \mathrm{~N}_{15} \mathrm{P}_{15} \mathrm{~K}_{15 \mathrm{~m}}$ & 37.0 & 11.6 & 474 & 30.0 \\
\hline \multicolumn{5}{|c|}{ Background $2-\mathrm{NH}_{4} \mathrm{NO}_{3 \mathrm{~m}}$} \\
\hline 1. Control & 37.2 & 12.0 & 478 & 30.0 \\
\hline 2. BisolbiFit & 37.4 & 12.0 & 482 & 29.5 \\
\hline 3. $\mathrm{N}_{15} \mathrm{P}_{15} \mathrm{~K}_{15}$ & 38.4 & 11.6 & 488 & 27.0 \\
\hline 4. $\mathrm{N}_{15} \mathrm{P}_{15} \mathrm{~K}_{15 \mathrm{~m}}$ & 38.8 & 11.3 & 490 & 25.8 \\
\hline 5. ${ }^{1 / 2} \mathrm{~N}_{15} \mathrm{P}_{15} \mathrm{~K}_{15 \mathrm{~m}}$ & 37.7 & 11.3 & 488 & 27.2 \\
\hline \multicolumn{5}{|c|}{ Background $3-\mathrm{NH}_{4} \mathrm{NO}_{3}$} \\
\hline 1. Control & 37.0 & 12.1 & 474 & 31.5 \\
\hline 2. BisolbiFit & 37.3 & 12.0 & 478 & 29.0 \\
\hline 3. $\mathrm{N}_{15} \mathrm{P}_{15} \mathrm{~K}_{15}$ & 37.8 & 11.6 & 488 & 27.6 \\
\hline 4. $\mathrm{N}_{15} \mathrm{P}_{15} \mathrm{~K}_{15 \mathrm{~m}}$ & 38.0 & 11.5 & 486 & 27.0 \\
\hline 5. ${ }^{1 / 2} \mathrm{~N}_{15} \mathrm{P}_{15} \mathrm{~K}_{15 \mathrm{~m}}$ & 37.0 & 11.6 & 484 & 28.0 \\
\hline
\end{tabular}


In the control option the protein content in 3 studied backgrounds made respectively: $12.4,12,0,12,1 \%$. The studies showed that the increased yields led to a certain decrease of protein content in oat grains, which ranged from 11.3 to $12.4 \%$ and on average made $11.8 \%$. At the same time the lowest values of protein content in grain were observed in $2016(10.9-11.6 \%)$, which is caused by established conditions of culture vegetation. In 2018, the amount of it in the grain was maximum and varied from 12.4 to $13.2 \%$.

The correlation analysis showed that the weight of 1000 grains is in positive relation with yield and revealed a negative relation between yield and protein content in oat grain $(\mathrm{r}=-0.76)$ (Figure 2).

Besides, the assessment of the quality of oat grain shall consider such characteristics as grain-unit and hoodness. The mineral nutrition of plants also influenced the grain-unit: on average over the years of study it varied from 466 to $490 \mathrm{~g} / \mathrm{l}$. In the control option it made $470-478 \mathrm{~g} / \mathrm{l}$, in the option with BisolbiFit biopreparation (pre-sowing seed treatment) - 472-482 $\mathrm{g} / \mathrm{l}$, in the option with azophoska $\left(\mathrm{N}_{15} \mathrm{P}_{15} \mathrm{~K}_{15}\right)-480-488 \mathrm{~g} / \mathrm{l}$, in $\mathrm{N}_{15} \mathrm{P}_{15} \mathrm{~K}_{15 \mathrm{~m}}$ $-478-490 \mathrm{~g} / \mathrm{l}$, and in the option $1 / 2 \mathrm{~N}_{15} \mathrm{P}_{15} \mathrm{~K}_{15 \mathrm{~m}}-474-488$ $\mathrm{g} / \mathrm{l}$. In the 2 background with modified ammonium nitrate under pre-sowing cultivation, the largest amount of grain-unit was in option No. $4\left(\mathrm{~N}_{15} \mathrm{P}_{15} \mathrm{~K}_{15 \mathrm{~m}}\right)-$ the grain was more filled and coarse with a minimum percentage of hoodness compared to other options. It seems that not only films themselves, but also the magnitude of the air voids between them, as well as between shells and seed kernel, are important.

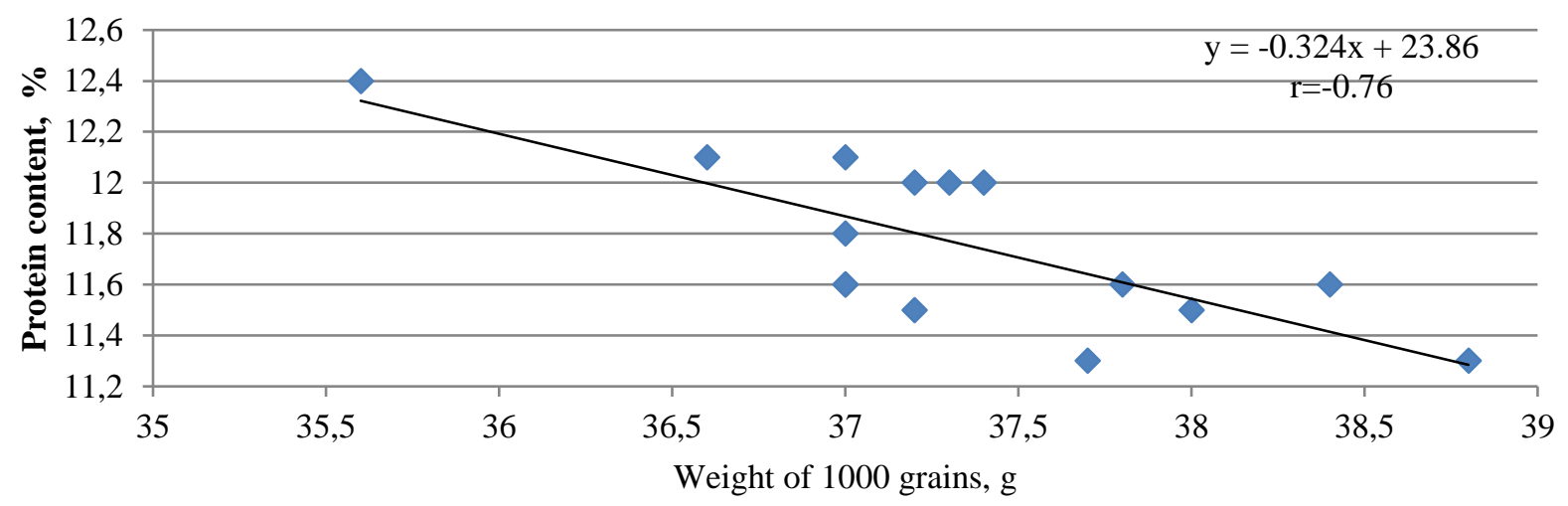

Fig. 2. Dependence of grain protein content on the weight of 1000 grains

Besides, oat availability depends on hoodness. Under different nutritional conditions of a plant this value decreased, its decrease to $27.3 \%$ was observed for option $\mathrm{N}_{15} \mathrm{P}_{15} \mathrm{~K}_{15 \mathrm{~m}}$. The use of mineral fertilizers and biopreparation influenced grain hoodness, the lowest percentage of hoodness was observed for the option $\mathrm{N}_{15} \mathrm{P}_{15} \mathrm{~K}_{15 \mathrm{~m}}$ in all studied backgrounds and made $27.3 \%$, $25.8 \%, 27.0 \%$, which is $4-5 \%$ lower than the control. Pre-sowing seed treatment did not have a significant impact on this indicator. The maximum value of grain hoodness was observed in the control option: 33, 30, 31 $\%$.

\section{Conclusion}

1. The use of biomodified Azophoska significantly increased oat grain yield in zero background by 6-7\%, in the background with biomodified ammonium nitrate under pre-plant cultivation by $9-12 \%$ and in the background with ammonium nitrate in pure form - by 6-11\% compared to traditional fertilizers.

2 . The correlation analysis made it possible to establish the dependence of yield on the main elements of the oat yield structure. Such indicators as the "number of productive stems - yield", "weight of grains in a panicle - yield", "weight of 1000 grains - yield" and the "number of grains in a panicle - yield" are marked by direct correlation, which coefficients made $0.76,0.86$, 0.88 and 0.81 respectively.
3. The mineral nutrition of plants influenced the grain-unit: on average over the years of study it varied from 466 to $490 \mathrm{~g} / \mathrm{l}$. The lowest percentage of hoodness was observed for the option $\mathrm{N}_{15} \mathrm{P}_{15} \mathrm{~K}_{15 \mathrm{~m}}$ in all studied backgrounds and made 27.3, 25.8, 27.0 \%, which is 4-5\% lower than the control.

\section{References}

1. Yu.A. Gavrilova, Efficiency of complex biomodified mineral fertilizers for barley on sod-podzolic light loamy soil, $\mathrm{PhD}$ dissertation, 20 (Moscow, 2018)

2. V.K. Chebotar, A.A. Zavalin, A.G. Aritkin, Application of biomodified mineral fertilizers (VNIIA, Moscow; UISU, Ulyanovsk, 2014)

3. A.A. Zavalin, L.V. Vinogradova et al., Geographical regularities of effect of inoculation with associative diazotrophs on the productivity of cereals, in Plant Microbial Interactions: Positive interactions in relation to crop production and utilization, Aspects of Applied Biology, 63, 123-127 (2001)

4. A.Kh. Kulikova, S.N. Nikitin, A.L. Toigildin, Biopreparations in the spring wheat fertilization system, Res. J. of Pharmaceut., Biolog. and Sci., 8(1), 1796-1800 (2017)

5. H. Junge, P. Krebs, M. Kilian, Strain selection, production and formulation of the biological plant 
vitality enhancing agent FZB24 Bacillius subtilis, Pflanzenschutz-Nachrichten Bayer, 1, 94-104 (2000)

6. A.N. Bondarenko, V.P. Zvolinsky, Microbiologic specimen in arid conditions, Farming, 3, 19-20 (2013)
7. Biological products in agriculture (methodology and practice of using microorganisms in crop and fodder production) (Moscow, 2005)

8. A.N. Bondarenko, V.P. Zvolinsky, Study of biological products based on associative nitrogenfixing microorganisms in the cultivation of spring sown cereal in Astrakhan Region, Agrochem. Bull., 2, 22-23 (2012) 